\title{
The Death of Koro Paka: \\ "Traditional" Māori Patriarchy
}

\section{Brendan Hokowhitu}

Deconstruction does not say there is no subject, there is no truth, there is no history. It simply questions the privileging of identity so that someone is believed to have the truth. It is not the exposure of error. It is constantly and persistently looking into how truths are produced. (Spivak I988, 28)

\footnotetext{
T
} his paper starts from the simple question of what knowledge is produced about Māori men and why. In Nietzschean style, I am less concerned with the misrepresentation of truths than with how such truths have come to be privileged. I do not argue that tropes such as the Māori sportsman, manual laborer, violent criminal, or especially the Māori patriarch, are "false," for indeed there are many Māori men who embody these categorizations. ${ }^{1}$ To propose such tropes are false would suggest that other forms of Māori masculinity are "truer," "more authentic" embodiments. Alternatively, I am stimulated to uncloak the processes that produce Māori masculine subjectivities. Specifically, this article deconstructs the invention, authentication, and re-authentication of "traditional" Māori patriarchy. Here, "invention" refers to the creation of a colonial hybrid. This is not to say, however, that colonization provided the environment for the genesis of Māori patriarchy, for it is probable that modes of Māori patriarchy existed prior to colonization (ie, patriarchy as constructed by Māori tribal epistemologies, focused on notions such as whakapapa [genealogy] and mana [power/prestige/respect]).

In order for this colonial invention to crystallize, it first required a catalyst. In the case of Māori patriarchy, as I describe in this article, the catalyst derived from the relational conditions between Pākehā and Māori. ${ }^{2}$ But, as these contours shifted, discourses oscillated from denigrations of

The Contemporary Pacific, Volume 20, Number I, II 5-I4I

(C) 2008 by University of Hawai'i Press 
the "savage" Māori male to celebrations of his noble warrior status, the recognition of affinities with the British, and the assimilation of Màori men to imperial models. The hybridized colonial invention established its authenticity over other modes as "true" Māori masculinity. This invented truth was cemented by the construction of Māori culture as premodern and, thus, static. In contemporary times, the invention is re-authenticated through narratives that establish continuity between a generalized Māori culture and a particular concept of patriarchy, and notions of authenticity and tradition. I examine these processes, first, by looking at how Māori patriarchy was invented and authenticated through the hybridization of Māori and British masculine cultures. Here I look particularly at the early colonial education of a select few Māori boys through British public schooling. I then look at the contemporary re-authentication of Māori patriarchy through a deconstruction of the film Whale Rider (Caro 2002). I argue that the film deploys a dangerous conflation of representation and reality, re-authenticating the invented tradition of Māori patriarchy.

\section{Mixed Beginnings: Hybridizing British Colonial Masculinity with the Noble Savage}

Many indigenous peoples are yet to detach themselves from colonial legacies, still embodied in the world and their persons. Colonial discourses constructed indigenous communities as "traditional" and "primitive," in opposition to colonizing Western "modern" cultures as enlightened and liberal. "Primitive," "traditional" societies supposedly incorporated mythical relationships with the natural world, like totemism, and, as Adam Kuper noted (I988), were allegedly ordered around a corporate family group ruled by a despotic patriarchy. The impact of colonization did not catalyze such traditions since there were precolonial continuities in Māori customs. Rather, what is crucial here is the colonial alignment of Māori culture with primitive inertia (ie, stagnation and failure to evolve/civilize). Ethnographic studies of "traditional" Māori society deceptively reconstructed a fictitious, ubiquitous traditional Māori culture. New Zealand missionaries, early European travelers, and anthropologists employed the word "traditional" to mean "Maori life before Europeans arrived in New Zealand" (Salmond I983, 3 I6). ${ }^{4}$ But, as Anne Salmond observed, notions of a traditional Māori culture were misleading in that no Pākehā method of investigation could ever adequately depict Māori life prior to colonization: "Bits and pieces of information from anywhere between I769 and 
I969 have been cobbled together in accounts of traditional behavior that included practices which never would have co-existed in any given Maori community at any given time" $(\mathrm{I} 983,3 \mathrm{I} 6)$. Tradition remains a fixating trope that arrests indigenous cultures (see Jolly I992).

Patriarchy is defined as "social organization marked by the supremacy of the father in the clan or family, the legal dependence of wives and children, and the reckoning of descent and inheritance in the male line; broadly, control by men of a disproportionately large share of power" (Webster 2003, 908-909). Though a supposed Māori "tradition," patriarchy is primarily a historical colonial construction. In many early colonial depictions the savage Māori man was portrayed as immoral, and sinful, and therefore in need of civilized enlightenment (Hokowhitu 2004a). The initial construction of Māori masculinity conformed to pervasive colonial discourses about "savage nations," which depicted indigenous male violence toward, and oppression of, indigenous women as indicative of a less civilized culture ruled by brute physical force (as opposed to the domination of women's passion by rational European men). Even when Māori male brutality was explained in more relativist terms, by decreeing Māori culture as "warlike," the generally accepted "truth" was that women were treated badly in uncivilized societies (Thomas I997, 8I).

Yet the martial character of Māori men was also endowed with positive qualities such as "physical prowess," "nobleness," and a "warrior spirit" (Hokowhitu 2002). Indeed, Māori were often seen as the most civilized of all savages, or as Jock Phillips put it, as "Aryan Māori," thus suggesting that Māori, of all the indigenous peoples, "were most like us [Pākehā]" (quoted in Schick and Dolan 1999, 56). The concept of Aryan Māori emerged in the debate about the origins of Māori. According to some, Māori were linked to Hindu India through language, custom, material culture, and physical appearance. Such a hypothesis genealogically tied Māori with Pākehā, if the Aryan Indo-European connection was also to be assumed (Ballantyne 2002, 62-68). The facts were disputed, but the Aryan Māori figure entered into popular culture, augmenting the narrative that both Māori and Pākehā were relatively recent arrivals to New Zealand, and both could claim noble origins. This narrative nurtured a humanist ethos in the new colony's interethnic relations, while legitimizing equal moral claims by Pākehā to New Zealand's natural resources.

Early European depictions of Māori men were thus not consistent. As a corpus they were ambiguous, faltering, and ambivalent toward the noble/ ignoble savage, and embroiled with "other forms of impassioned desire 
captivated by novel and particular things" (Thomas I997, I6), which compromised any claims to "scientific validity." Early travelers often crossed paths with indigenous peoples who contravened their prior expectations of primitive societies. Nevertheless, as Linda Tuhiwai Smith contended, early travelers' tales were an intrinsic part of colonial discourses, which romanticized the savage Other as part of a natural physical world filled with "innocence and purity," as opposed to the "corruption and decay" of modern Europe (I999, 49). The noble savage offered a romantic account of a naive and mystical life prior to industrialization. Accordingly, positive representations of the savage offered the possibility of a connecting humanism, providing colonizers with a bridge to recognize good in their darker brethren (especially if that was crossed through conversion to Christianity). Indeed, the noble savage figure remained the most common portrayal of Māori in the decades following 1900.

Still, through a Foucauldian understanding of rupture (Foucault 2002, 28-29), it can be seen that as the colonial New Zealand context changed, so did the conditions of Māori-Pākehā relations and the associated objects of knowledge. Thus, as the antagonistic settler morphed into the colonial co-resident/assimilator, the underlying concepts of savagery remained in the dominant discourses surrounding Māori, as they transformed from violent savage, to noble savage, to hued citizen. Interestingly, both Ty $\mathrm{P}$ Kāwika Tengan and Isaiah Helekunihi Walker (this issue) highlight the discontinuity between colonial discourses of masculinity in Hawai'i and New Zealand. While Māori hypermasculinity was privileged in New Zealand, Hawai'i as a place was feminized and Hawaiian men were seen as "emasculated." Later, modes of colonized masculinity in Hawai'i became polarized between the lazy, sensual, and resistant, and the hardworking, disciplined, and compliant. Yet there were important similarities between Hawai'i and New Zealand, in the disciplining of indigenous masculine bodies through elite private boys' schools and manual labor (see Tengan, this issue). Differing discourses of hegemonic masculinity between Hawai'i and New Zealand can be explained by varying forms of subjugation and divergent transformations in colonial relations. For instance, the initial violent resistance by Màori men in the I86os Civil Land Wars and their subsequent complicity with the British war effort in the First and Second World Wars promulgated divergent discourses of Māori male violence as ignoble and noble. The discourse of ignobility justified colonial violence, subjugation, and land annexation, while the later discourse of nobility served to assimilate and endear Māori men to the New Zealand 
public; both fitted their respective historical contexts. The tension between noble and ignoble adjudications of Māori male violence was naturalized as an ambivalence that still resonates today, especially in popular culture. Ambivalences in the construction of Hawaiian men as ignoble or noble warriors perhaps derive from similar shifts in colonial contexts (see Tengan, this issue).

As Māori survived their predicted natural demise, ${ }^{5}$ the settler population realized cohabitation was inevitable. In accordance with the assimilation policy of the period, the "modern" Māori appeared capable of performing the rudiments needed to participate at the base levels of colonial society. Late nineteenth-century texts explicitly distinguished between the "real Māori" of the past and the "brown-skinned citizens" of today. The former were "romantic, cloaked, tattooed warriors, poets and hunters. ... Maoris had done so well for savages that their achievements could be compared with those of the British in the remote past" (McGeorge I993, 69). Māori had demonstrated a "greater aptitude for civilization than any other barbarous race" (Cornwell I88I, 330). The widely used education resource texts, The Imperial Readers, stated, "Maori were savages but noble savages" (Whitcombe and Tombs I 899, 83). While "brown-skinned citizens" and "noble savages" were distinguished, the Pākehā public were, in part, convinced that Māori should be admitted as New Zealand citizens because of their noble past. Māori nobility had an appeal to Pākehā civilians versed in the class formations of British culture and the imperial celebration of warrior valor.

The noble savage concept morphed with British imperial patriarchal values to produce a hybrid Māori patriarchy, now thought to be symptomatic of "traditional" Māori masculinity. The hybridized forms of culture produced by the colonial union were, thereafter, seen as definitive of traditional indigenous culture. Moreover, before colonization, there was no pan-Māori national identity, so, prior to around I840 (the year when New Zealand's founding document, the Treaty of Waitangi, was signed), ${ }^{6}$ there was no generalized, homogenized concept of Māori masculinity. Such masculinity was a creation of the Pākehā imagination: Māori men only came to think of themselves as "Māori" men through the Pākehā gaze.

The imperial system Māori men inherited afforded them power simply because they were men, and Māori men were not entirely resistant to embracing this privilege. To suggest otherwise would be to debilitate their agency. Māori culture came "perilously close" to extinction and, to 
avert such a dire consequence, Māori men were compelled to assert themselves "in playing more decisive roles in determining their own futures" (Durie I998a, 54)—even if, ironically, such roles served British imperialism. Māori men assumed those British masculine qualities that would abet their integration into the dominant Western culture (Hokowhitu 2005). Māori men's compliance is understandable as both a political strategy and as a cultural survival mechanism. The Māori population had radically decreased from precolonial estimates of as high as 500,000 (and as low as 200,000 ) to a population of 56,000 in I $857-1858$ (Durie I998b, 29-30). By I 874, Māori had become "only fourteen per cent, a minority in their own country" (Durie I998a, 53). Patriarchy served the useful purpose of aligning Māori culture with that of their invaders. It enabled a small segment of the Māori population insights into the world of their oppressors. For their communities, the burgeoning Māori gentry automatically became symbols of the path to survival in a world where the very fabric of tribal life had been ripped asunder.

This is not to say, however, that Māori male leaders shed their tikanga Māori (Māori culture) and merely adopted wholesale the attributes of their Pākehā brethren. The world they faced was a hybrid one and, accordingly, Māori culture had to rapidly transform to survive, sometimes replicating Pākehā culture, sometimes forging hybrid compromises, sometimes creating cultural bastions (such as the marae [communal meeting place]) and deploying subversive methods to keep their culture alive. In a way akin to Frantz Fanon's observations regarding Black masculinity, colonial denigration of Māori culture led Māori men to assert themselves: "Since the other hesitated to recognize me, there remained only one solution: to make myself known" (Fanon I986, I I). Thus, many Māori cultural practices that persist today are consequences of the colonial milieu, some ape nineteenth-century British culture, and others remain incomprehensible to Western epistemologies, but none, either combined or singly, correspond to a "traditional Māori masculinity." In the following section I examine the emergence of a hybrid Māori patriarchy in a more specific context: the training of young Māori gentry in a British-style public school system.

\section{Hybridizing Māori Leadership: Te Aute and the SChooling of MĀori Gentlemen}

The previous section highlighted how Māori survival required some complicity with Pākehā systems, and how colonial discourses about Māori 
had transformed in the early decades of the twentieth century from those emphasizing savagery to those stressing obligatory assimilation and citizenship. An assembly of educational institutions designed to indoctrinate Màori in the ways of their colonizers was thus necessary. The colonial policy of creating a cultural divide between generations, and the increasing desire by Māori to be educated in Pākehā ways, led to the education of a select few Māori boys in elite, British-style colonial institutions. Subsequently an elite group of Māori men was created, who learned the British masculine leadership system and who were intended to be advocates of the system among their communities.

Te Aute College was conceived as a place where young Māori men could be groomed in the fashion of the English gentry. Founded in I 854 , Te Aute presented "an extraordinary blend of various colonial legacies. Over the past I 20 years, Anglicanism, Maoritanga [Māori culture] and rugby have combined to form a unique New Zealand institution ... . [where Māori] families sent their chosen sons to be educated in a replica of the nineteenth century English boarding school” (MacDonald I996, I3-I4). In I89I, headmaster John Thornton founded the students' association of Te Aute (originally known as the Association for the Amelioration of the Condition of the Maori Race). The association had "an underlying agenda of assimilation and the abolition of 'injurious' customs and 'useless' meetings ... [and] advocated a reduction in gift-giving at weddings and tangihanga [funerals], and abandonment of the custom of burying grave goods with deceased persons" (Walker I990, I73). Later named Kotahitanga mo Te Aute (Unity for Te Aute), the association aimed to use students as a "'machine' and 'hands to do the work' to advance the well-being of the people." Part of the association's mandate was the advocacy of sport as an integrative practice, along with "dairying and horticulture" (Walker I990, I73).

In New Zealand's private boys' schools, sport was an important cog in the machine of British imperialism. The culture of the rugby field was designed to impart features of imperial masculine leadership: "courage, endurance, assertion, control and self-control" (Dimeo 2002, 80). Rugby, in particular, as a form of "muscular Christianity," became readily promoted at Te Aute to impart desirable attributes of manly virtue, that is, the "acceptance of authority, perseverance against the odds, the ability to lead and to win or lose gracefully" (MacDonald I996, 5). Initially, Thornton advised against Māori playing rugby because of it being "too violent a contact sport, which was likely to cause injuries and rouse the 
passion and fighting spirit of the Māori” (Walker I990, I75). Accordingly, he suggested Māori boys play the gentlemanly sports of cricket and tennis. Not dissuaded, "in the years ahead [Māori] were to become passionately devoted to rugby" (Walker I990, I75). Some of the many Te Aute schoolboys of note who played for either the All Blacks, ${ }^{7}$ the New Zealand Māori, or both, were Tom Ellison, David "Davy" Gage, Wiri Nehua, "Alex" Ariki Marehua Takarangi (MBE), Wiremu Teihoka Parata (OBE), Taituhu Peina, W R Akuira, Samuel Gemmell, Waata "Pat" Potaka, Jack Ruru, William "Bill” Potae, and George Skudder. In turn, many of these men were also linked to the political arena or directly involved in it. Jack Taiaroa, who scored nine tries for New Zealand in the I884 tour to Australia, was commonly described as the "prince of footballers" (MacDonald I996, I6) and was son of Hori Kerei Taiaroa who served as a member of Parliament for Southern Māori from I 87 I-I 885 and on the Legislative Council from I 88 5-1905. Tom Ellison, in I 89 I, became the first Māori to be admitted to the New Zealand Bar and stood unsuccessfully for Parliament three times (McLean I987, II). Henry "Mick" Kenny's father was a British Army officer who later became member of Parliament for Picton I 868-I88I. John Hopere Wharewiti Uru played rugby and cricket for Canterbury and was a member of Parliament for Southern Māori from I9I8-I92I. Tiaki Omana (Jack Ormond) was a member of the Pioneer Māori Battalion in World War I and represented Eastern Māori in Parliament from I943-1963. Manuera "Ben" Couch was elected a member of Parliament in 1975 and became Māori Affairs minister in 1978.

The intention in listing these men is to draw attention to the interrelationship between Te Aute (and other elite Māori boys' schools), rugby, and Māori male colonial leadership, but it should be noted that this relationship did not automatically mean passivity in the colonization process. Jack Taiaroa's father, Hori, for instance, "waged a lonely campaign to bring Ngai Tahu [a South Island tribe] land claims to the attention of the European administration" (MacDonald I996, I6). Tom Ellison, Hori Taiaroa's nephew and Jack Taiaroa's younger cousin, "took up his uncle's case on behalf of Ngai Tahu" (MacDonald I996, I6) when he stood for Parliament. Ironically, Ellison was the first official (ie, sanctioned by the New Zealand Rugby Football Union) captain of a New Zealand team that toured Australia in I 893. Today it seems inconceivable that a person like, for example, Peter Sharples or Moana Jackson (both Māori political activists), would be captain of the All Blacks national rugby union team. 
Evidently many of the men described here had the best interests of their people in mind, whether that was through resistance to colonial domination or assimilation. Many of the Māori gentlemen who came out of places like Te Aute became leaders in their communities; they were strong, competent, eloquent, and able to function between both worlds. Later, as a testament to how far elite Māori masculinity mirrored the British gentry's dominant masculinity, Viscount Bledisloe (one of New Zealand's most respected governor-generals) said at the centenary of the Kaiapohia $\mathrm{Pa}$ (communal gathering space) that Māori (ie, the Māori gentleman) "could at least vie with his British comrade in loyalty, dignity, refinement, athletic achievement and eloquent speech" (quoted in Slatter I970, I70).

The importance of hybridization to a burgeoning colonial Māori masculine leadership can be seen in this well-known adage written by Sir Apirana Ngata (a famous Māori leader, Te Aute old boy, first Māori university graduate, and member of Parliament):

E tipu, e rea, mō ngā rā o tôu ao;

ko tō ringa ki ngā rākau a te Pākehā hei ara mō tō tinana;

ko tō ngākau ki ngā taonga a ō tīpuna Māori hei tikitiki mō tô māhuna;

à, ko tō wairua ki tō Atua nāna nei ngā mea katoa.

Grow up o tender plant in the days of your age

Your hands to the implements of the Pakeha

For your bodily well-being

Your mind to the treasures of your ancestors

To adorn your head

Your spirit to God

Who created all things. (quoted in Winiata I967, I83)

It must be stressed that schools such as Te Aute were not the norm for the majority of Màori boys. Until the I940s, state education overtly discriminated against Māori by providing them with curricula focused on manual instruction (Hokowhitu 2004a). In the curricula of Native Schools, for example, "academic" subjects were largely prohibited from being taught. ${ }^{8}$ Indeed, Thornton was chastised by the educational hierarchy for providing Te Aute students with opportunities in academic subjects. During the mid-nineteenth century, the achievement of Te Aute students in math, science, and literature was equal to any in the country, producing scholars and political leaders such as Ngata, Sir Maui Pomare, and Sir Peter "Te Rangihiroa” Buck. In I866, Inspector of Native Schools 
James Pope complained about the academic achievement at Te Aute, suggesting that the school should be an institute where "Maori boys could be taught agriculture, market gardening, stock farming, poultry keeping and bacon curing; and yet all the resources of the estate were being diverted to literary work" (quoted in Barrington I988, 47). As a result, Inspector General of Schools George Hogben asked Te Aute authorities to drop many of the academic subjects from the curriculum. Elsewhere, with no School Certificate courses in Native Schools, most Māori could not compete to attain professional employment, and consequently the formation of a Māori middle-class did not eventuate. ${ }^{9}$

This discussion draws attention to the tensions and inconsistencies occurring in the colonial context. Neither Pope's dichotomization of mental (Pākehā) versus Māori (manual) labor nor Thornton's humanism, for instance, were ubiquitous. The noble/ignoble ambivalence generated a tension between divergent techniques that various colonial administrators chose to promote Māori integration. Some Pākehā attempted to mirror British class distinctions (possibly in accordance with the "Aryan Māori" concept) by creating a Māori nobility. Conversely, other Pākehā, especially government educational administrators, strongly adhered to their belief that imparting a British public school style of education would do little for a savage culture whose only destiny was to provide labor for settler landowners.

The result mirrored the British class system in the sense that a miniscule Māori gentry provided British-style leadership to an overwhelming majority of working-class Māori. Yet the majority of the Māori gentry described here could not emulate the British landed gentry because they had lost much of the land they would have presided over, through wrongful land confiscation by the settler government. Hence, a hybridized form of elite Māori masculinity developed that was partially based on British dominance and Māori deference but was also molded by indigenous concepts and values, such as whakapapa and mana, as opposed to possession of capital. This hybridized form of Māori male leadership is clearly evident in the patriarchal character Koro Paka in the film Whale Rider. While Koro embodies many of the characteristics of a nineteenth-century British patriarch, his mana is clearly not determined by ownership of capital, or even control over a landed estate, but rather by genealogical ties to spiritual ancestors. In the section to follow, I interpret how Whale Rider re-authenticates the invention of traditional Māori patriarchy. 


\section{WHALE Rider}

Whale Rider is a New Zealand feature film of unprecedented international success. ${ }^{10}$ Briefly, Whale Rider tells the story of a young girl, Paikea, who demonstrates many leadership qualities (photo I). But patriarchal tradition supposedly prevents her grandfather, Koro, from seeing Paikea as the natural future leader of their tribe. The film establishes itself as a valid "ethnographic" text, blurring representation and reality so that, rather than just simulate Māori culture, it generates a "simulacrum, which, although the product of the system, also acts as the external referent by which it justifies its function" (Sim 200I, 358). The culture portrayed is not Māori

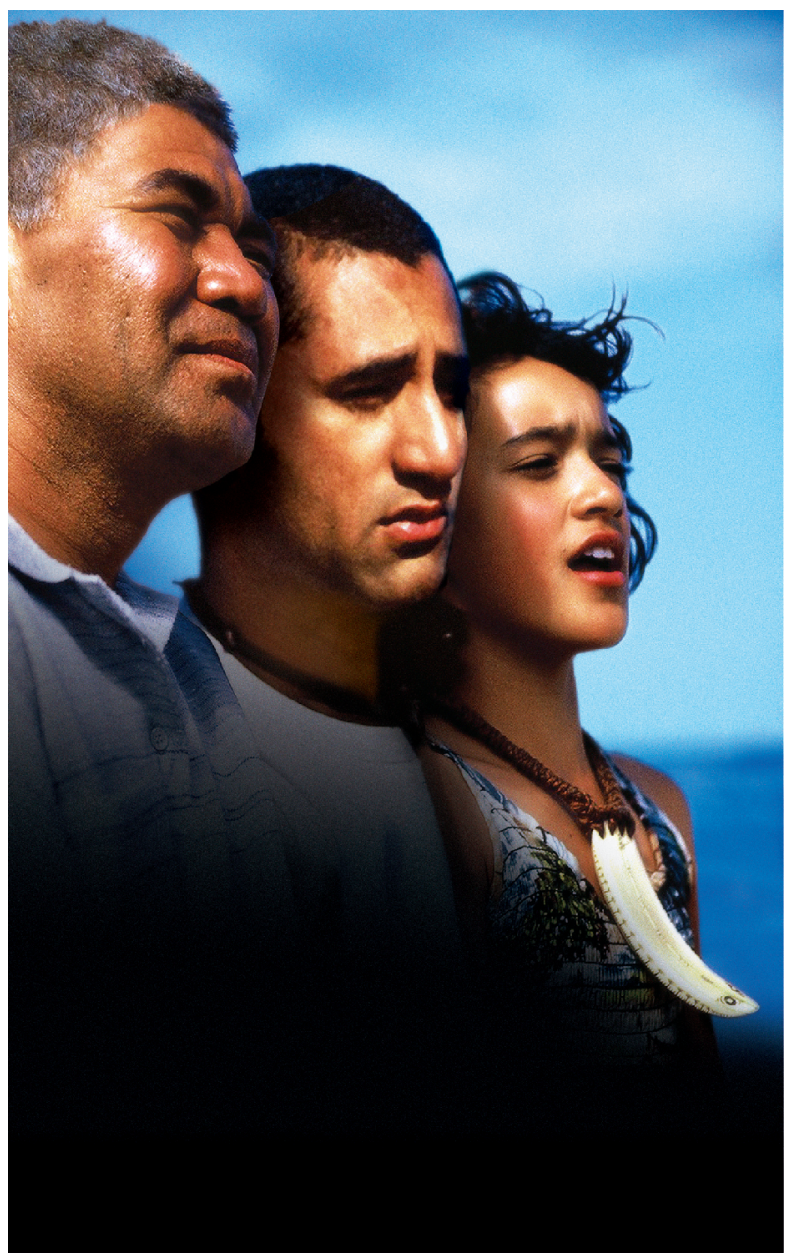

Рното г. Whale Rider poster image (Paikea pictured at far right, her father Porourangi in the center, and her grandfather Koro at far left). (C) South Pacific Pictures Limited 2002. Photo by Kirsty Griffin. 
culture, but rather a "third culture" located somewhere beyond New Zealand's national boundaries (Watson I997, 226). Such a third culture, like any commodity, is created for, and controlled by, market demand, and its "factories" are indigenous localities reproduced for consumption by global/local culture. Speaking of the transnational manufacturing of the "underdog" story in an indigenous setting, Whale Rider producer John Barnett explained: "This is a universal story, these themes of inherited power and the clash between the contemporary and the traditional, the familial love and the obligations that Koro the chief has that get in his way of exercising that familial love, the role of a woman in society-those were things that it didn't matter where you came from in the world, you were familiar with" (quoted in Welch 2003, 2I). Ultimately, he added, "What it encourages you to do is make a product that people want to go and see" (quoted in Welch 2003, 23). The result is that a Western audience watches not just a story about the Other, but a story about themselves.

\section{The Neocolonial Gaze: Whangara Fantasyland}

Jean Baudrillard speaks of hyperreality to indicate the loss of the real, where distinctions between surface and depth, the real and the imaginary no longer exist (I988). Akin to nineteenth-century travelers' tales, which told of marvelous exotic locales, the popular film genre that Western audiences increasingly enjoy draws on ethnographic tropes and styles, and purports to represent an-Other's reality. As evidenced in one film reviewer's comments: "Whangara is a community frozen in time, waiting to be saved. ... Whale Rider gives us clear-eyed glimpses of rural Maori society, from the old women smoking and playing cards, to the local kids in their American-branded T-shirts, kicking their heels until they're old enough to leave" (Morris 2003, I8).

The film purposefully infuses its illusory fiction with markers of "authentic reality." For instance, local viewers would know that Whangara (where Whale Rider was set) is a locale in the tribal area of Ngāti Porou (North Island, middle east coast). The names "Porourangi" and "Paikea" derive from famous ancestors of the Ngāti Porou people, and Paikea is the eponymous ancestor, the original "whale rider." Caro populates Whangara the fantasyland with extras from the actual Whangara community. This "fact" was highlighted in the film's hype and marketing campaign (photo 2). For global audiences less familiar with Māori culture, Whale Rider depicts a more anonymous but authentic primitive culture and place, grounded in 


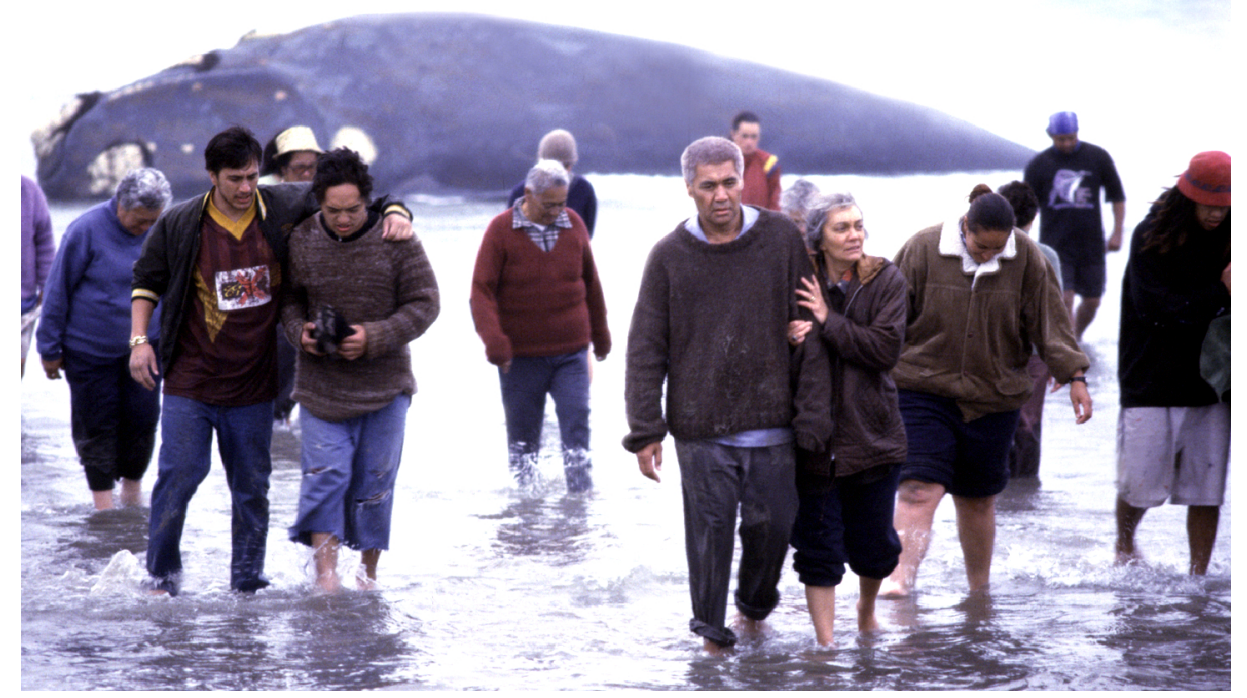

Рното 2. Villagers at whale stranding. (C) South Pacific Pictures Limited 2002. Photo by Kirsty Griffin.

kinship relations, fossilized ceremonies, and traditions of totemism (Kuper I988, 7, 234-235). The Whangara they see is not just an invented community bonded through intimate connections with spiritual forebears, shared myths, and memories, but also accompanied by real-world referents such as the marae and the whales themselves, simulating a Māori rural coastal reality. Importantly, to paraphrase Benedict Anderson, it is not the falsity or genuineness of communities that should be distinguished, but rather how they are imagined (I98I, 6).

Caro's descriptions of her on-set experiences reflect the conflation of representation and reality: "There are many Maori communities there, and it's like going back to the I950s and I960s sometimes. Children are still going to school on horses. It's wonderful" (quoted in Garcia 2003 b, I6). ${ }^{11}$ Film reviews also suggested how markers of authenticity in the film suggested a "realistic depiction": "Director Niki Caro ... shows a genuine sympathy for the traditions of the conservative patriarchal society her film describes ... we come to appreciate the rhythms of village life" (Cunneen 2003, I 8). The acceptance by Western audiences of Whangara as an "authentic" place speaks to the naturalization of privileged representations of indigenous cultures and ignores the vested interests of the producers. The imagined reality of Whangara as backward, depressed, devolving, 
and led by despotic patriarchy is established as typical of an indigenous community.

\section{Where Have All the Pākehā Gone?}

Whale Rider offers the illusion of spatial isolation allowing viewers, like early anthropologists, to focus on the rich particularity of local traditions, and to escape into a world where images of themselves are not present. Whangara assumes many of the characteristics of a Disney fantasyland-a timeless, childlike world, free from the hegemony of the powerful adult. The emptiness and simplicity of the physical and social landscape in Whale Rider enables the neocolonial gaze to consume the Other, without acknowledging their own presence. Moreover, the presence of Pākehā in the film would have disrupted the idea that what the audience was witnessing was Māoridom in an authentic traditional state. Thus, Pākehā are absent, with the exception of Porourangi's German wife, who is seen only at the very end and has a nonspeaking role.

Like a colonial painter (Andreassen 2003, I8), Caro has removed the backdrop of the colonial reality and, in so doing, purged Pākehā and other Westerners of any responsibility for the oppression of indigenous peoples. In the simulacrum of Whangara, a Western audience can recognize ubiquitous human themes in an exotic locale, while the colonial process that produced the subjugation of Mãori is rendered invisible. According to the film, Māori malaise is due to a lack of visionary leadership, despite one bundred fifty years of colonial oppression. The absence of Pàkehā in the film suggests that the self-determination of Māori is entirely within their grasp; by finding a visionary leader the tribe will then be able to "paddle off" into an enlightened future. In truth, the violent cultural disruption caused by colonization has had profound effects on the self-determination and social consciousness of Māori and, in particular, precipitated dysfunctional Māori men. According to Whale Rider, however, Māori male dysfunction is solely a result of the limitations of traditional Māori beliefs: patriarchy and rank hierarchy. ${ }^{12}$

Using a Freudian analysis, we might see Caro acting as a censor in the repression of one narrative with another. By voiding the film set of Pākehā, Caro has allowed Western colonial guilt to remain in the unconscious. Unsurprisingly, Pākehā have embraced this movie because it promotes a conscious paternalistic narrative of nurturing a savage culture while repressing the role of Pākehā in the oppression of Māori. Accordingly, 
Caro admitted the film's appeal to Pākehā: "What I did not anticipate was Pakeha New Zealanders responding in exactly the same way. They're going to the film in droves and they're coming away saying, 'That's us. That's who we are. That's what we're proud of'" (quoted in Garcia 2003 b, I6).

\section{Enlightening Whangara: Lineage and Patriarchy}

Thus, Whale Rider is a film in which fiction masquerades as authentic reality, and in that process the re-authentication of the invented tradition of Māori patriarchy is central. The successful simulation of "primitive patriarchy" in Whale Rider has led film reviewers in particular to fail to differentiate between representation and reality. The lack of distinction between the film's surface and the deeper reality it purports to represent has promoted a hyperreal Māori masculinity as abhorrently patriarchal, in contrast to the allegedly benign gender relations of the West.

Whale Rider represents Māori culture as patriarchal, sexist, and encumbered by tradition. The readiness of the Western audience to accept this representation as authentic is not surprising, given that it is conterminous with a dominant discourse surrounding indigenous cultures in general. Film reviewers seemed keen to affirm this version of Māori reality: "Whale Rider immediately places us within a family of chieftains at the end of its tether. We quickly learn that the fate of a disintegrating community rides on the question of succession and ancestry. ... The Ngāti Konohi line [a tribe from the east coast of the North Island] is traditionally the preserve of patrimony, and extends as far back into the time when forefather Paikea was saved by a whale" (Aoun 2005, I73).

For film reviewer Rick Cline, Koro "blatantly (and traditionally) prefers boys to girls" and is "blinded" by "traditional sexism" (2003). Likewise, Stacie Stukin proposed, "The movie reveals a sexist Maori culture in which knowledge and lineage are passed down only along the male line" $(2003,46)$. And clearly, Caro herself believes that Māori patriarchy is endemic: "This young girl is fighting over a rooo years of patriarchal tradition" (quoted on E-News Extra 2003). While I am unwilling to present a counter "truth" to these constructions of Māori culture, I find it particularly ironic that Caro's Whale Rider promulgates patriarchal tradition under the banner of Ngāti Porou culture, given the real-world prominence of Ngāti Porou women leaders. Indeed, Apirana Mahuika's I 973 master's thesis, "Ngā Wāhine Kai-hau-tū o Ngāti Porou," acknowledges the significance of the great women leaders of Ngāti Porou by showing their 
pivotal role in "naming descent groups, houses, places, and in claiming and exercising mana" (Salmond I983, 324).

The depiction of male domination in other cultures as hegemonic (Connell I995) is a common contemporary signifier that the culture is unenlightened (hooks 2004). This reaffirms the superiority and power of the West. While Western masculinities in recent times have allegedly enjoyed an androgynous fluidity associated with the "new man" (Beynon 2002), Other masculinities (such as those of African, Islamic, or Māori men) have been continually constructed as untransformed and frozen in time. Dominant white masculinities are privileged as hegemonic while masculinities rooted in different epistemologies are denounced as abhorrent and undemocratic. Thus, white men retain their power, which by contrast with Other systems of governance, is seen as inherently rational, egalitarian, and non-patriarchal. The Western mainstream media's attack on the oppression of Islamic women in Arab countries, for example, is less about the fate of Islamic women, and more about the depiction of Arab nations as backward and irrationally fundamentalist in comparison to the West's democracy. Indeed, in talking of the film, Witi Ihimaera (the author of the novel, The Whale Rider, on which the film was based) regrettably made this very connection: "It matters and it doesn't matter that it's in a Maori setting. I would love to be in an audience of Arabic women wearing their fabulous masked gear watching that movie, and hoping that they find some sense of liberation in it" (quoted in Matthews 2003, 2I).

Accordingly, Whale Rider and its director have been celebrated for bridging "the ancient world of Maori myth and the contemporary world of gender politics" (Ansen 2003, 59). Caro has been hailed as the creator of an emancipatory film: "Confident, perspicuous and unflappable, Caro talks easily about how the subtext of her film-the rise of a new consciousness, of a peculiarly feminine perspective-is supremely important to her as an artist" (Garcia 2003 b, I6). Caro "has put feminist inspiration into the movie showing the girls and boys what leadership is made of" (Stukin 2003, 46). Such interpretations clearly fail to notice that Caro's creation is not a feminist film at all. I would go so far as to say that Whale Rider betrays the precepts and values of most Western feminisms (which argue that men should not have monopoly on power simply because they were born men). The film inadvertently defends hereditary power by privileging Paikea's right to leadership, irrespective of gender, through being a direct descendant of her forefather and namesake, implying that leadership should be genealogically predetermined. Paikea's understanding of 
her own positioning in the world is not so much a feminist reaction to patriarchy or even a personal claim to be recognized as a female leader in her own right. Rather, she answers a "higher calling" based on her genealogy.

\section{Re-authenticating Patriarchy}

The most disturbing aspect of Whale Rider is its promotion as an emancipatory film for Māori. Such a discourse assumes that, in alignment with the film's "coming of age" theme, Māori culture is in need of enlightenment. Paikea is the "martyr" for this cause. I use the word "martyr" here even though Paikea does not die. The possibility of her death is imagined as the path to rebirth and enlightenment. Caro surely intended the audience to at first envisage her death, through Paikea's willing descent into the depths of the dark ocean atop the lead whale. With Koro's long-awaited realization of Paikea as a "natural" leader, at this point, the purpose of the film had been achieved-Willy had been freed. ${ }^{13}$

Through making the prepubescent Paikea focal to the project of cultural enlightenment, Caro effects the transcendence of a primitive culture by an enlightened one: "The preadolescent girl is a paradoxical character because despite being young, she is wiser and more knowing than the adult characters who share her screen-space" (Message 2003, 86). Caro suggested that Paikea as a modern subject is inherently more sagacious than her ancestors: "Pai [Paikea] is suffering tremendous opposition from her grandfather who she loves the most, and she's the one person in the film who won't criticise him. She looks for other ways to love him and make him see. She empowers everybody around her. She gets so deeply hurt but never loses sight of who she is. That is real leadership, the kind of leadership that is appropriate for our time" (quoted in Garcia $2003 \mathrm{~b}$, I6).

The isolation of Whangara also serves to signify it as a borderland, where the "sea" of homogenized Western culture approaches the "shores" of a fictional local traditional Māori village, a place at the margins of the global world, just as the community is on the margins between primitivity and modernity. Its unenlightened characters are as "restless as the sea... the beach is its iconic point of entry and departure, a place where people are abandoned or disappear forever, a place where things wash up" (Morris 2003, I 8). The film's setting on the beach connotes the vastness of the world (represented by the sea) that lays beyond Whangara, as well as the 
insular nature of the small community hemmed in by landscape and tradition-a locale stuck in the hinterland between pre-modernity and modernity. While Whangara has some of the trappings of industrialization, such as cars, buses, and motorboats, these only serve to highlight the ineffectuality of a stagnant culture in grasping modernity. Industry penetrates the primitive space, but that space envelops and corrodes advanced technology so that, like the broken motorboat chord and the rusting car-wrecks, people and place are subjected to devolution.

Paikea occupies this boundary space geographically and physiologically as a member of the tribe and as a character fluctuating between childhood and adulthood. Only the wise innocence of the preadolescent enables the leap of faith needed to enter the enlightened adult world. Without Paikea and without liberalized Western norms, Māori culture, like the unfinished waka (canoe), remains dormant: "Pai's actions are those of an enlightened being, of a person who knows her place in the world. For Pai, power is a thing to be shared. She smashes hierarchies, just as she shatters the classic notions of leadership" (Garcia 2003a, 43). The portrayal of the return home of Porourangi (Koro's eldest progeny and Paikea's father) underlines such enlightened promises. He will only return home if Māori culture changes to enlightened globalized norms. While the child, Paikea, can claim martyrdom in the name of modernity, it is clear that the tribe's postmodern fate lies with the baby lying in the womb of Porourangi's German wife. Menacingly, the hybrid child symbolizes the tribe's sealed destiny of becoming an indigenous component of global culture-like her father's creations in the visual arts. By blurring national and cultural boundaries, the infant's genealogical lines symbolize postindustrial, transnational agendas.

Traditional Māori patriarchy is portrayed as the chief encumbrance to the enlightenment project. By sublimating this assumption beneath an overlaying rhetoric of liberation via Pākehā direction, the film implores Māori to seek emancipation by conforming to Western enlightenment values. As one film reviewer suggested: "Whale Rider contains a lesson. It shows how drastic action is necessary to achieve social change, how the responsibility lies with both the individual and the community. Just as Pai is delivered back to her family by the sea, Maori society needs to be reborn-fresh-faced, determined, and informed. . . . Its final scene, in which Porourangi's waka strikes out to sea, Pai and Koro sitting side by side, suggests the beginning of a journey as great as the Pacific voyages 
of old. The purpose this time isn't to find new land, but to create a new world in the place where they live" (Morris 2003, I8). But in contrast, I would argue that the re-authentication of Māori patriarchy and the alignment of Māori emancipation with European enlightenment marks Whale Rider as a problematic and even dangerous film for the project of Māori decolonization.

Recently I was asked, "Why criticize a film where Māori culture is the central theme, and where Māori are afforded so much international kudos?" Indeed, indigenous people from around the world have embraced the film and are often surprised by my criticism. I support the film's themes that challenge modernity's secularism, the abandonment of spiritual connections with the natural world, and the deterioration of community. To be sure, the reenvisioning of a pre-enlightened Self, seeking spiritual connections with the natural world and surrounded by an insular community, is part of the film's appeal for indigenous and nonindigenous audiences alike. Indigenous people are not immune to sentimentality and the idealism of humanism. Yet I believe there is a very real danger that the persuasive humanistic romanticism of this simulacrum can dupe indigenous people into confusing the representation with reality. I would suggest that through the privileging of certain portrayals of Màori culture and the "Disneyfication" of a complex neocolonial context, the film freezes and fixates traditional Māori culture as patriarchal. Just as Koro chastises Porourangi for selling sculptures to Europeans by invalidating his son's art as "not work" but "souvenirs," I chastise the filmmakers for creating a simplistic and possibly dangerous depiction. As Barclay asserts, Whale Rider is an "indigenous film for beginners"; he goes on to say, "All films about indigenous people are described as indigenous but it is perplexing that we are past the day when we talk about a black film if the director is white or a woman's film if the director is a man yet we are asked to see a film by a Pakeha as a Maori film” (quoted in Calder 2003).

\section{Changing Morals: The Passing of Patriarchy}

Renounce the convenience of terminal truths. (Foucault 200I, xi)

The challenge that Foucault wields in relation to Māori patriarchy is for Māori to realize that no representations of Māori culture are inherently truthful; that no forms of Māori masculinity are more authentic than others. To buy into the notion that Māori culture can be "authenticated" is 
to align with the colonizer. The hybridization of Māori masculinity and British patriarchy must be acknowledged as an out-of-date performance, which resulted from colonial circumstances but no longer serves an integrative function, and should be discontinued - the death of Koro Paka, if you will. This challenge does not refer to patricide as such. Rather I am alluding to Foucault's "death of man" (2002), in which he claims that the very concept "man" (as a self-contained rational agent) was the creation of a unique set of historical contingencies. Similarly, I believe the very concept of the Māori patriarch to be a consequence of certain relationships of power, and an illusion of colonial discourse. To appreciate such an idea is not easy, for the decolonization of our minds, especially apropos the "traditional," can disrupt the very core of what is considered "Māori."

Unfortunately, when deconstructing truths about Māori masculinity, the question that naturally follows is, "Well, what is the 'truth' about Māori men, then?" This question bemuses me because of the absence of an equivalent question in discourses surrounding white masculinity. Perhaps the same essentialisms are not required in understandings of white men, who after all are imagined as self-contained, rational agents. I refer back to Nietzsche: Why do we want truth? Why not "untruth"? In other words, the purpose of this article is not to seek a singular truth about Māori masculinity, but rather to challenge those truths favored by the dominant discourse-to challenge the very concept of the Mãori patriarch as a credible tradition. Aligning with Gayatri Spivak's claim that it is impossible to distill the essence of subaltern subjectivities, I suggest any conceptualization of an "authentic" or "traditional" Māori man is an illusion.

It will be difficult for Māori masculinity to escape the confines of the Othering process. History suggests that images of Other men are so entrenched in the fears of white men that we will have to struggle to throw off the shackles of these images, nurtured in the popular imagination through films like Whale Rider. History also teaches us, however, that Māori culture has transformed in order to survive: the whakatauākì (proverb) "Te ao hurihuri, te ao marama" (The changing world, the world of light) suggests that change is inherent in the world and inevitable, and that knowledge and growth are keys to survival in a changing world. Given this, I believe Māori culture will terminate the untruth of traditional patriarchy. The challenge is to "direct" and produce our own knowledge and to be critical of the knowledge produced for us and by us. 
I WOULD LIKE TO DEDICATE this article to my brother, Thomas "Jason" Kerehama Hokowhitu, who passed away while it was being written (I I Sept I967-I I June 2006).

I would like to thank Margaret Jolly, Vilsoni Hereniko, and Kevin Fisher as well as two anonymous reviewers for their helpful comments on earlier drafts of this paper.

\section{Notes}

I "Māori" is a generic word that initially meant "normal" but has come to incorrectly represent the tribal-based indigenous peoples of New Zealand. Mason Durie said about being Māori: “Before European contact, the word Māori simply meant normal or usual. There was no concept of a Māori identity in the sense of cultural or even national similarities.... The original inhabitants of New Zealand did not refer to themselves as Māori; rather they were Rangitāne or Ngāti Apa or Tūhoe or any of forty or more tribes" (I998a, 53).

2 In recent years, the term "Pākehā" has been made controversial by rightwing misinterpretations of the word and its origins in derogatory meanings such as "evil spirit," "pig," and "flea." Such misrepresentations aim to distance dominant white New Zealand culture from the perils of Māori definition, and to augment the cultural divide between Māori and Pākehā. In actuality, the word "Pākehā" stems from precolonial words such as "pakepakehā" and "pākehakeha" (and the like) common to certain parts of the Pacific, referring to "Imaginary beings resembling men, with fair skins" (Williams I975, 252). From this largely innocuous, visual understanding of the word and its transference to the white colonists invading New Zealand, "Pākehā" has evolved throughout colonization to commonly refer to "New Zealander of European descent" (Moorfield 2005, I08), forming the inverse cultural construction of the word "Māori" in the binary relationship that has defined New Zealand bi-ethnic relations for one hundred sixty years or more.

3 It should be pointed out that this binary does not mean that Pākehā culture is void of traditions; rather, it is the tight connection of tradition and primitivity that differentiates Western from indigenous traditions.

4 Many writers employ "Aotearoa/New Zealand" to depict the nation-state. I refrain from employing "Aotearoa" because it implies that there was or is such a thing as a Māori nation; the popularized use of this term symbolizes the idea of a united and contented people living under a "long-white-cloud."

5 In the mid to late-nineteenth century, it was commonly thought that the Māori people would die out naturally, as predicted by the "survival of the fittest" philosophy of some evolutionary thinkers.

6 I recognize the signing of the Treaty of Waitangi in relation to the genesis 
of the concept of Māori because it was the first time that Pākehā attempted to convene a unified "Māori" voice.

7 The All Blacks are New Zealand's national rugby union team.

8 See Barrington I988, Simon I998, and Hokowhitu 2004b for further reading.

9 I do not have space in this article to fully explain the imposition of colonial masculinities onto Māori boys through education and sport. For further reading see Hokowhitu 2003a, 2003 b, 2003c, 2004a, 2004b, 2005.

Io From the outset, a clear distinction must be made between the film Whale Rider (Caro 2002) and Witi Ihimaera's book, The Whale Rider (1992). In my opinion, the book is far more complex than the film and does not warrant the same criticism leveled at the film.

I I Of particular relevance to patriarchy and third culture is one of the "deleted scenes" available to be viewed in the "special feature" section of the Whale Rider DVD. In the relevant scene, Koro uses a shovel to manually dig a septic tank behind the marae. The eldest son, Porourangi, joins Koro in the task, following which a typical polarizing dialogue between father and son (exemplifying traditional resistance versus modern insights) ensues. Yet both men, in their laboring, perform working-class masculinities. The scene is revealing because it demonstrates that Māori hierarchical patriarchy (embodied by Koro) is not determined by typical symbols of British class. In her commentary regarding why this particular scene was deleted from the film, director Caro implies that the international audience would fail to grasp why a leader would be digging a septic tank.

I2 This was also the underlying message in the film Once Were Warriors (Tamahori I994).

I 3 This refers to the plot of the movie Free Willy (Wincer I993), about a boy's successful efforts to free a captive orca (killer whale). It is also a play on words referring to the humanistic concept of "free will," inherent to modernism.

\section{References}

Anderson, Benedict

I98I Imagined Communities: Reflections on the Origin and Spread of Nationalism. New York: Verso.

Andreassen, Rikke

2003 The "Exotic" as Mass Entertainment: Denmark I878-I909. Race and Class 45 (2): I-39.

Ansen, David

2003 Movie Review of Whale Rider directed by Niki Caro. Newsweek, 9 June, 59 . 
Aoun, Steven

2005 Video Review of Whale Rider directed by Niki Caro. Metro Magazine I 43 (Winter): I73.

Ballantyne, Tony

2002 Orientalism and Race: Aryanism in the British Empire. Cambridge: Palgrave.

Barrington, John

I988 Learning the "Dignity of Labour": Secondary Education Policy for Maoris. New Zealand Journal of Educational Studies 23:45-58.

Baudrillard, Jean

I988 America. Translated by C Turner. London: Verso.

Beynon, John

2002 Masculinities and Culture. Buckingham, uk: Open University Press.

Calder, Peter

2003 Riding High on "Whale" Tale World Report: New Zealand Success of Whale Rider Promotes New Zealand Film Industry. Variety 393 (5): A2.

Caro, Niki, director

2002 Whale Rider. Feature film, 97 minutes. Produced by Tim Sanders, John Barnett, and Frank Hübner. Auckland: South Pacific Pictures.

Cline, Rich

2003 Review of Whale Rider, directed by Niki Caro. Shadows on the Wall [film e-zine]. http://www.shadowsonthewall.co.uk/oz/whalride.htm

Connell, R W

I995 Masculinities. Berkeley: University of California Press.

Cornwell, James A

I88 I School Geography. London: John Murray.

Cunneen, Joseph

2003 Youthful Tales: Maori Girl, Animated Fish Enliven Summer. National Catholic Reporter 39 (34): I 8.

Dimeo, Paul

2002 Colonial Bodies, Colonial Sport: "Martial" Punjabis, "Effeminate" Bengalis and the Development of Indian Football. International Journal of the History of Sport I9 (I): 72-90.

Durie, Mason

I998a Te Mana, Te Kāwanatanga: The Politics of Māori Self-Determination. Auckland: Oxford University Press.

I998b Whaiora: Māori Health Development. Second edition. Auckland: Oxford University Press.

E-News Extra

2003 Review of Whale Rider, directed by Niki Caro. Broadcast on E-News 
Extra television program, New Zealand Sky Entertainment Channel, November.

Fabian, Johannes

I983 Time and the Other: How Anthropology Makes its Object. New York: Columbia University Press.

Fanon, Frantz

I986 Black Skin, White Masks. London: Pluto.

Foucault, Michel

$200 \mathrm{I}$ Madness and Discourse. London: Routledge.

2002 The Archaeology of Knowledge. London: Routledge.

Garcia, Maria

2003a Buying \& Booking Guide Movie Review of Whale Rider, directed by Niki Caro. Film Journal International Io6 (6): 43.

2003 b Whale Tale: New Zealand's Niki Caro brings Maori Legend to Life. Film Journal International Io6 (6): I6.

Hokowhitu, Brendan

2002 Te Mana Māori - Te Tātari ngā Korero Parau. PhD thesis, University of Otago, Dunedin.

2003a Māori Physicality: Stereotypes, Sport and the "Physical Education" of New Zealand Māori. Culture, Sport, Society 6 (2): I92-2 I 8.

2003b Māori Masculinity, Post-structuralism, and the Emerging Self. New Zealand Sociology I 8 (2): I79-20I.

2003c Race Tactics: The Racialised Athletic Body. Junctures I:2 I-34.

2004a Tackling Māori Masculinity: A Colonial Genealogy of Savagery and Sport. The Contemporary Pacific 16:259-284.

2004b Te Tāminga o te Mātauranga Māori: Colonisation in Education. In Ki te Whaiao: An Introduction to Māori Culture and Society, edited by Tania Ka'ai, John Moorfield, Michael Reilly, and Sharon Mosley, I90-200. Auckland: Pearson.

2005 Rugby and Tino Rangatiratanga: Early Māori Rugby and the Formation of "Traditional” Māori Masculinity. Sporting Traditions: Journal hooks, bell of the Australian Society for Sports History 2I (2): 75-95.

2004 We Real Cool: Black Men and Masculinity. New York: Routledge.

Ihimaera, Witi

I992 The Whale Rider. Auckland: Reed.

Jolly, Margaret

I992 Specters of Inauthenticity. The Contemporary Pacific 4:49-72.

Kuper, Adam

I988 The Invention of Primitive Society: Transformations of an Illusion. London: Routledge. 
MacDonald, Finlay

I996 The Game of Our Lives. Auckland: Penguin.

Mahuika, Apirana

I973 Ngā Wāhine Kai-hau-tū o Ngāti Porou. Master's thesis, University of Sydney.

Matthews, Phillip 2003 Myth Making. New Zealand Listener I 87 (3273): I 8-24.

McGeorge, Colin

I993 Race, Empire and the Maori in the New Zealand Primary School Curriculum. In The Imperial Curriculum: Racial Images and Education in the British Colonial Experience, edited by Tony Mangan, 64-78. London: Routledge.

McLean, Terry P

I987 New Zealand Rugby Legends. Auckland: Moa.

Message, Kylie

2003 Whale Rider and the Politics of Location. Metro Magazine I36 (Spring): 86.

Moorfield, John

2005 Te Aka: Māori-English, English-Māori Dictionary and Index. Auckland: Pearson.

Morris, Paula

2003 Review of Whale Rider, directed by Niki Caro. Cineaste 29 (I): I 8.

Salmond, Anne

I983 The Study of Traditional Maori Society: The State of the Art. Journal of the Polynesian Society 92 (2): 309-33I.

Schick, Ruth, and John Dolan

I999 Masculinity and a Man's Country in I998: An Interview with Jock Phillips. In Masculinities in Aotearoa/New Zealand, edited by Robin Law, Hugh Campbell, and John Dolan, 46-64. Palmerston North, NZ: Dunmore Press.

Sim, Stuart, editor

200I The Routledge Companion to Postmodernism. London: Routledge.

Simon, Judith

I998 Ngā Kura Māori: The Native Schools System I867-1969. Auckland: Auckland University Press.

Slatter, Gordon

I970 On the Ball: The Centennial Book of New Zealand Rugby. Christchurch, NZ: Whitcombe \& Tombs.

Smith, Linda Tuhiwai

I999 Decolonizing Methodologies: Research and Indigenous Peoples. Dunedin, NZ: University of Otago Press. 
Spivak, Gayatri

I988 Subaltern Studies: Deconstructing Historiography. In Selected Subaltern Studies, edited by Ranajit Guha and Gayatri Chakravorty Spivak, 3-32. New York: Oxford University Press.

Stukin, Stacie

2003 Niki Caro. Ms. Magazine I3 (4): 46.

Tamahori, Lee, director

I994 Once Were Warriors. Feature film, IO2 minutes. Fine Line Features; a Communicado film in association with the New Zealand Film Commission, Avalon Studios, and New Zealand on Air.

Thomas, Nicholas

I997 In Oceania: Visions, Artifacts, Histories. Durham, NC: Duke University Press.

Walker, Ranginui

I990 Ka Whawhai Tonu Matou: Struggle Without End. Auckland: Penguin Books.

Watson, James

I997 Transnationalism, Localization, and Fast Foods in East Asia. In Golden Arches East: McDonald's in East Asia, edited by James Watson, 222232. Stanford, CA: Stanford University Press.

Webster

2003 Merriam-Webster's Collegiate Dictionary. Eleventh edition. Springfield, MA: Merriam-Webster, Incorporated.

Welch, Denis

2003 The Producer. New Zealand Listener I 89 (3295): 20-24.

Whitcombe and Tombs

I 899 The Imperial Readers. Christchurch, nZ: Whitcombe and Tombs Ltd. Williams, H W

I975 A Dictionary of the Māori Language. Seventh edition. Wellington: A R Shearer, Government Printer. First published in I 844 .

Wincer, Simon, director

I993 Free Willy. Feature Film, I I 2 minutes. Hollywood: Warner Brothers.

Winiata, Maharaia

I967 The Changing Role of Leader in Maori Society. Auckland: Blackwood and Janet Paul.

\section{Abstract}

This article is underpinned by the simple question of what knowledge is produced about Māori men and why. In particular, it deconstructs the invention, authentication, and re-authentication of "traditional” Māori patriarchy. It begins 
by examining how Māori patriarchy was invented and authenticated through the hybridization of Māori and British masculine cultures, especially through the early colonial education of a select few Māori boys, who were subjects of a British public schooling technique. The article draws from this historical analysis to demonstrate how Māori patriarchy continues to be authenticated in today's popular culture. Here, the contemporary re-authentication of Māori patriarchy is drawn attention to through a deconstruction of the film Whale Rider. This film analysis argues that Whale Rider deploys a dangerous conflation of representation and reality, which ultimately re-authenticates the invented tradition of Māori patriarchy. The article is less concerned with denouncing particular tropes of Māori men as "false" and more with how such "truths" have come to be privileged; it also seeks to uncloak the processes that produce Mãori masculine subjectivities.

KEYWORDS: Māori, masculinity, patriarchy, film, Whale Rider, sport, rugby 